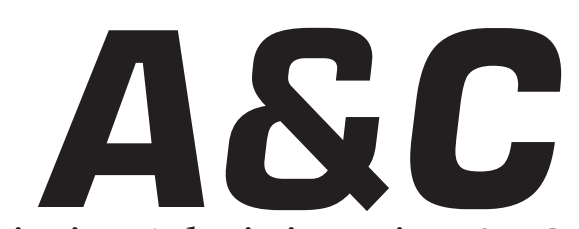

Revista de Direito Administrativo \& Constitucional

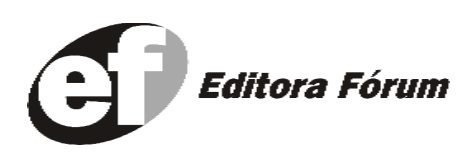

A\&C R. de Dir. Administrativo e Constitucional, Belo Horizonte, ano 4, n.16, p. 1-255, abr.jun. 2004 


\section{A\&C REVISTA DE DIREITO ADMINISTRATIVO E CONSTITUCIONAL}

\section{IPDA}

Instituto Paranaense

de Direito Administrativo

Direção Geral

Romeu Felipe Bacellar Filho

Direção Editorial

Paulo Roberto Ferreira Motta

Direção Executiva

Emerson Gabardo

Conselho de Redação

Edgar Chiuratto Guimarães

Adriana da Costa Ricardo Schier

Célio Heitor Guimarães

Conselho Editorial

\section{Adilson Abreu Dallari Lúcia Valle Figueiredo}

Alice Gonzáles Borges Manoel de Oliveira Franco Sobrinho

Carlos Ari Sundfeld (in memoriam)

Carlos Ayres Britto Marçal Justen Filho

Carlos Delpiazzo Marcelo Figueiredo

Cármen Lúcia Antunes Rocha Márcio Cammarosano

Celso Antônio Bandeira de Mello Maria Cristina Cesar de Oliveira

Clèmerson Merlin Clève Nelson Figueiredo

Clóvis Beznos Odilon Borges Junior

Enrique Silva Cimma Pascual Caiella

Eros Roberto Grau Paulo Eduardo Garrido Modesto

Fabrício Motta Paulo Henrique Blasi

Guilhermo Andrés Muñoz Paulo Neves de Carvalho

Jorge Luís Salomoni Paulo Ricardo Schier

José Carlos Abraão Pedro Paulo de Almeida Dutra

José Eduardo Martins Cardoso Regina Maria Macedo Nery Ferrari

José Luís Said Rogério Gesta Leal

José Mario Serrate Paz Rolando Pantoja Bauzá

Juan Pablo Cajarville Peruffo Sérgio Ferraz

Juarez Freitas Valmir Pontes Filho

Julio Rodolfo Comadira Yara Stropa

Luís Enrique Chase Plate Weida Zancaner

Os conceitos emitidos em trabalhos assinados são de responsabilidade de seus autores, que gozam de inteira liberdade de opinião. e-mail para remessa de artigos, pareceres e contribuições: e.gab.@uol.com.br

ou conselho@editoraforum.com.br Endereço para envio de contribuições: Editora Fórum

Revista A\&C, Av. Afonso Pena, 2770, 15\%16ª andar, Funcionários, CEP 30130-007 - Belo Horizonte - MG

A\&C Revista de Direito Administrativo e Constitucional. Ano 3, n. 11, jan./mar. 2003. Belo Horizonte: Fórum, 2003.

Trimestral

ano 1, n.1, 1999 até ano 2, n.10, 2002 publicada pela Editora Juruá em Curitiba

ISSN: $1516-3210$

1. Direito Administrativo. 2. Direito Constitucional. I. Fórum.

CDD: 342 CDU: 33.342
Editor responsável: Luis Cláudio Rodrigues Ferreira Projeto gráfico: Luis Alberto Pimenta

Diagramação: Anderson Pimenta

Revisora: Olga M. A. Sousa

Pesquisa jurídica: Fátima Ribeiro - OAB/MG 74868 Bibliotecária: Nilcéia Lage de Medeiros -

CRB 1545/MG - 6 a região

(C) Editora Fórum Ltda 2004.

Proibida a reprodução total ou parcial desta obra, por qualquer meio eletrônico, inclusive por processos xerográficos, sem autorização expressa do editor.

Distribuída em todo o território nacional

Assinaturas e comercialização:

Editora Fórum, Av. Afonso Pena, 2770, 15-16 andar, Funcionários, CEP 30130-007 - Belo Horizonte - MG Tel.: (31) 2121-4900 - 0800 704-3737

e-mail: editoraforum@editoraforum.com.br site: www.editoraforum.com.br 


\title{
O Controle dos Poderes Executivo e Legislativo pelo Supremo Tribunal Federal
}

\author{
Mauro Roberto Gomes de Mattos \\ Advogado no Rio de Janeiro. Vice Presidente do Instituto Ibero Americano de Direito Público - IADP, \\ Membro da Sociedade Latino-Americana de Direito do Trabalho e Seguridade Social, Membro do \\ IFA - Internacional Fiscal Association. Conselheiro efetivo da Sociedade Latino-Americana de Direito \\ do Trabalho e Seguridade Social
}

Sumário: 1 Introdução - 2 O poder e o seu limite - 3 Desvio de poder administrativo - 4 O Supremo Tribunal Federal e o controle do abuso de poder administrativo - 5 Desvio de poder legislativo - 6 O Supremo Tribunal Federal e o abuso do poder legislativo - 7 Conclusão

\section{Introdução}

O artigo inaugural da Constituição Federal elenca a República Federativa do Brasil como um Estado Democrático de Direito, formado pela UNIÃO indissolúvel dos Estados, Municípios e do Distrito Federal.

A consagração de um Estado Democrático, feita pelo constituinte atual, tem como escopo afastar o autoritarismo e a concentração de poder, que, segundo Alexandre de Moraes, ${ }^{1}$ são inerentes à natureza humana:

O Estado Democrático de Direito significa a exigência de reger-se por normas democráticas, com eleições livres, periódicas e pelo povo, bem como o respeito das autoridades públicas aos direitos fundamentais.

\section{Ou para Celso Antônio Bandeira de Mello:²}

Estado de Direito é a consagração jurídica de um projeto político. Nele se estratifica o objetivo de garantir o cidadão contra intemperanças do poder público, mediante prévia subordinação do poder de seus exercentes a um quadro normativo geral e abstrato, cuja função precípua é conformar efetivamente a conduta estatal a certos parâmetros antecipadamente estabelecidos como forma de defesa dos indivíduos.

Assim, é seu propósito estabelecer real empecilho a que tais limites sejam ultrapassados e - se a despeito disso o forem - assegurar que os comportamentos violados do direito sejam fulminados, impondo-se aqueles que seriam devidos, além das separações patrimoniais cabíveis.

${ }^{1}$ MORAES, Alexandre de. Constituição do Brasil Interpretada. São Paulo: Atlas, 2002, p. 131.

${ }^{2}$ MELLO, Celso Antônio Bandeira de. O Controle Judicial dos Atos Administrativos. RDA 152:112.

A \& C R. de Dir. Administrativo e Constitucional, Belo Horizonte, ano 4, n. 16, p. 77-106, abr./jun. 2004 
Canotilho e Vital Moreira, ${ }^{3}$ em laço de extrema felicidade, assim sublinham sobre o alcance do princípio democrático:

... a articulação das duas dimensões do princípio democrático justifica a sua compreensão como um princípio normativo multiforme. Tal como a organização da economia aponta, no plano constitucional, para um sistema econômico complexo, também a conformação do princípio democrático se caracteriza tendo em conta a sua estrutura pluridimensional. Primeiramente, a Democracia surge como um processo de democratização, entendido como processo de aprofundamento democrático da ordem política, econômica, social e cultural. Depois, o princípio democrático recolhe as duas dimensões historicamente consideradas como antiéticas: por um lado, acolhe os mais importantes elementos da teoria democrática - representativa (órgãos representativos, eleições periódicas, pluralismo partidário, separação de poderes); por um lado, dá guarida a algumas das exigências fundamentais da teoria participativa (alargamento do princípio democrático a diferentes aspectos da vida econômica, social e cultural, incorporação de participação popular direta, sem conhecimento de partidos e associações como relevantes agentes de dinamização democrática, etc.).

Pois bem, o Estado Democrático de Direito criou a constitucionalização das normas da Administração Pública como uma forma de garantir o controle do poder efetivo através do cumprimento das normas constitucionais, sendo eleito o Poder Judiciário como o responsável pelo controle externo e final dos vários segmentos públicos. Ou pela dicção de José Cretella Júnior: "O controle jurisdicional do ato da Administração é, assim, uma das características mais inequívocas do Estado de Direito, onde impera o regime da legalidade." ${ }^{4}$

Estas normas vêm cristalizadas nos princípios e preceitos básicos da Administração Pública, constitucionalizados a partir da promulgação da Carta de 1988.

Nessa retórica, com a fixação desses conceitos básicos (princípios e preceitos) constitucionais, ficou bem delimitado o perímetro do poder, com a ampliação da ingerência do Poder Judiciário nos negócios (atos) da Administração Pública.

Esta permanente fiscalização do Poder Judiciário tem como escopo garantir a aplicação dos princípios constitucionais lançados como uma bússola a ser seguida pelos agentes públicos e Administradores, quando das suas atuações para impulsionar a máquina administrativa.

Assim, por exemplo, quando o Judiciário declara inconstitucional

${ }^{3}$ CANOTILHO, J.J.; MOREIRA, Vital. Fundamentos da Constituição. Coimbra: Coimbra Ed., 1991, p. 195.

${ }^{4}$ CRETELLA JR., José. Controle Jurisdicional do Ato Administrativo. 2. ed. Forense, 1992, p. 112.

A \& C R. de Dir. Administrativo e Constitucional, Belo Horizonte, ano 4, n. 16, p. 77-106, abr./jun. 2004 
alguma norma legal, determinando a aplicação de princípio constitucional violado, não está legislando positivamente, e sim mantendo eficaz a própria Constituição.

Sobre essa passagem, tivemos a oportunidade de deixar consignado: ${ }^{5}$

Têm-se, portanto, que em função da constitucionalização das normas da Administração Pública, o Poder Judiciário amplia o seu leque de controle sobre os atos do Estado. Não se trata de legislar positivamente, pois compete ao judiciário interpretar e aplicar as normas legais, em especial o que vem contido na Constituição. Retirar do Judiciário essa prerrogativa seria o mesmo que engessar os direitos e garantias fundamentais que a Constituição radia para a sociedade. Por mais discricionários que possam ser os critérios da política legislativa, encontra nos princípios constitucionais a primeira e mais fundamental de suas limitações.

Em cumprimento de sua indelegável função, o Poder Judiciário fica autorizado a aferir e penetrar na essência da construção do ato emanado pelos demais Poderes, para verificar se é o mesmo moral, legal, impessoal, eficiente, e se cumpre o requisito da publicidade. Partindo-se dessas premissas, o STF vem coibindo abusos praticados pelos agentes públicos, quando não cumprem o que vem estatuído no caput do art. 37 da CF, definindo, dentre outros, quais os atos imorais praticados; os requisitos possíveis para o ingresso na carreira pública (art. 37, II); a atuação de Comissões Disciplinares (at. $5^{\circ}, \mathrm{LV}$ ) e de Inquérito Parlamentar (art. 58, § $3^{\circ}$ ); os limites da publicidade oficial (art. 37, II); poder de tributar (art. 145); a violação à intimidade do administrado (art. $5^{\circ}, \mathrm{X}$ e II); o respeito à coisa julgada, ato jurídico perfeito e a irretroatividade das leis (art. $5^{\circ}$, XXXVI) etc.

Com a codificação constitucional dos preceitos básicos do direito administrativo, a tarefa de controlar o Poder ficou mais elástica e mais contundente, tendo em vista uma construção jurisprudencial sólida do STF e demais Cortes Revisoras, que, como guardiãs da legalidade, limitam a atuação pública ao que vem elencado na Constituição Federal.

Com a maestria de sempre, Alexandre de Moraes ${ }^{6}$ destacou:

A construção jurisprudencial do STF e dos demais órgãos jurisdicionais, principalmente a partir da Constituição de 1988, decorrente da interpretação das regras básicas da Administração Pública previstas na Constituição Federal, caracterizou-se pelo caráter criativo e limitador do Poder Executivo, buscando a consagração da transparência, moralidade e probidade na gestão da coisa

\footnotetext{
${ }^{5}$ MATTOS, Mauro Roberto Gomes de. A Constitucionalização das Regras da Administração Pública e o Controle do Poder Judiciário. Revista do Instituto Ibero Americano de Direito Público, v. VII, jan./mar. 2002, p. 119-120. ${ }^{6}$ MORAES, Alexandre de. Constituição do Brasil Interpretada. São Paulo: Atlas, 2002, p. 770.
} 
pública em defesa dos direitos dos administrados.

E Jean Rivero ${ }^{7}$ já ensinava:

O direito administrativo é largamente jurisprudencial. É um traço fundamental. Obrigado a resolver litígios para os quais a lei não lhe fornecia qualquer princípio de solução, o juiz teve de construir, muitas vezes completamente, a regra que iria aplicar.

Dito isto, se verifica que o STF, autorizado pela Constituição, vem coibindo abuso ou excesso de poder por parte dos demais Poderes. Esta interferência, legalmente autorizada, não invade a regra da independência dos poderes, em razão do Judiciário ser o fiel responsável pelo acompanhamento da correta execução das normas constitucionais voltadas ao Poder Público.

\section{0 poder e o seu limite}

$\mathrm{Na}$ atuação dos Poderes da União, que são independentes e harmônicos entre si, (art. $2^{\circ}$ da CF), o Legislativo, Executivo e o Judiciário, devem pautar seus atos com lealdade constitucional (vergassungsteve).

Lealdade constitucional, segundo Canotilho, ${ }^{8}$ "compreende duas vertentes, uma positiva, outra negativa. A primeira consiste em que diversos órgãos do poder devem cooperar na medida necessária para realizar os objetivos constitucionais e para permitir o funcionamento do sistema com o mínimo de atritos possíveis. A segunda determina que os titulares dos órgãos do Poder devem respeitar-se mutuamente e renunciar a prática de guerrilha institucional, de abuso de poder, de retaliação gratuita ou de desconsideração grosseira. Na verdade, nenhuma cooperação constitucional será possível sem uma deontologia política, fundada no respeito das pessoas e das instituições e num apurado sentido da responsabilidade do Estado (status man ship)".

Por lealdade constitucional, os Poderes são obrigados a agirem em conformidade com os ditames constitucionais.

Como o Poder Público decorre de uma função autorizada, que se atribui ao órgão, dentro de uma jurisdição que lhe é traçada pela lei, e impulsionado por agentes públicos, que se apresentam como delegados do próprio Estado, "salta aos olhos" que o dever de lealdade constitucional é o mínimo

${ }^{7}$ RIVERO, Jean. Direito Administrativo. Coimbra: Almedina, 1981, p. 36.

${ }^{8}$ CANOTILHO, J.J.; MOREIRA, Vital. Os Poderes do Presidente da República. Coimbra: Coimbra Ed., 1991, p. 71.

A \& C R. de Dir. Administrativo e Constitucional, Belo Horizonte, ano 4, n. 16, p. 77-106, abr./jun. 2004 
que se exige para que não ocorra transbordamento ou abuso de poder.

Abuso de poder pode ser verificado pela exorbitância dos poderes conferidos aos agentes públicos, ou pela insuficiência de motivo ${ }^{9}$ de interesse público.

$\mathrm{Ou}$, segundo Pontes de Miranda: ${ }^{10}$

Abuso de poder é o exercício irregular do poder. Usurpa poder quem, sem o ter, procede como se o tivesse. A falsa autoridade usurpa-o; a autoridade incompetente que exerce poder que compete a outrem, usurpa; a autoridade competente não usurpa; se de modo exorbita, abusa do poder.

A atual Constituição, alargando o espectro da Carta de 1967, muniu o cidadão de remédios judiciais específicos, tais como o Habeas Corpus (art. $5^{\circ}$, LXVIII) e o Mandado de Segurança (art. $5^{\circ}$, LXIX), para proteção contra os atos ilegais ou abusivos emanados do poder constituído.

Para o ilustre Caio Tácito, ${ }^{11}$ autor de obra específica sobre o tema, "a noção de abuso de poder de autoridade administrativa (equivalente ao excés de pouvoir do direito francês) é o reverso do princípio de legalidade da Administração pública, nascido com o liberalismo político".

O princípio da legalidade é uma das peças mestras do Direito Administrativo, decorrendo do acatamento da lei pelo Poder Público. Ou, pelas palavras de Rafael Entrerra Cuesta: ${ }^{12}$

Dicho principio postula que la Administración se rometa em todo momento a lo que la Ley estabelezca. Y cuando empleamos el término 'Ley' lo hacemos em su más amplio sentido... Por ello há hecho fortuna la expresión según la cual la Administración haberá de rometese no ya a la ley, sino a todo el 'bloque de la legalidad!

Assim, o limite do poder é a lei, onde a Constituição é peça fundamental dessa engrenagem.

\section{Desvio de poder administrativo}

A máquina administrativa se locomove através de atos administrativos, baixados por autoridade competente, sempre vinculado a uma norma de direito, que visa cumprir determinado interesse público.

No trato da coisa pública, a Administração busca o interesse coletivo,

\footnotetext{
9 "O Ato Administrativo discricionário torna-se arbitrário e nulo por falta de motivação legal." (BRASIL. Supremo Tribunal Federal. Rel. Min. Thompson Flores, RE n 69.486, Pleno, RDA 108:276)

${ }^{10}$ MIRANDA, Pontes de. Comentários à Constituição de 1967. 3. ed. Forense, 1987, v. V, p. 313

11 TÁCITO, Caio. Abuso de Poder Administrativo. Departamento Administrativo.

12 ENTRERRA CUESTA, Rafael. Curso de Derecho Administrativo. 2. ed. Madrid, v. 1, p. 116.
} 
distanciando-se, ao máximo, de interesses individuais do agente público responsável pelo ato.

Nesse sentido, feliz é a lição de Caio Tácito: ${ }^{13}$

Não trata a autoridade de interesse próprio ou individual. A ação que exerce tem como endereço uma finalidade pública, que não pode descumprir.

Enquanto no ato jurídico as razões que inspiram o autor, bem como o objetivo a ser alcançado, são, via de regra, indiferentes à validade do ato, o mesmo não ocorre com o ato jurídico público e, especialmente, como o ato administrativo.

Qualquer ato administrativo está vinculado a um fim público, ainda que a norma de competência a ele não se refira.

A manifestação de vontade do agente público terá, necessariamente, que se dirigir à observância da finalidade específica com a natureza da atividade exercida.

Se a autoridade se desvia da finalidade legal específica, o ato administrativo se torna viciado em elemento essencial à sua legalidade.

Caracteriza-se, na hipótese, o vício que se conceituou como desvio de finalidade ou desvio de poder.

O abuso de poder se verifica quando a autoridade que baixa o ato não possui competência para tal fim, ou quando descumpre a lei ou qualquer outro ordenamento legal, para atingir "alvo diverso daquele que lhe é determinado", desviando-se da finalidade pública.

A título de ilustração, no sistema francês, visando coibir os excessos, os princípios gerais de direito são utilizados na esfera administrativa pelo Conselho de Estado da França, que delimita e reduz o poder discricionário da Administração.

Em nosso país, o ato discricionário sofreu profundas transformações após o advento da Constituição de 1988, pois o STF permite que se invada a essência do ato para confrontá-la com o que vem estatuído na Carta Magna sobre a Administração Pública.

Em outras palavras, após a atual Constituição Federal, o administrador não poderá usar da sua discricionariedade para, movido por um fim pessoal, desacatar, por exemplo, os princípios da legalidade, moralidade, publicidade, eficiência e a impessoalidade (art. 37, da CF).

Historicamente, em 1869, surgiu a primeira edição das "Conferências sobre o Direito Administrativo", de M. Aucoc, onde foi introduzida a

\footnotetext{
13 TÁCITO, Caio. O Desvio de Poder no Controle dos Atos Administrativos, Legislativos e Jurisdicionais. RDA 228, p. 1.
}

A \& C R. de Dir. Administrativo e Constitucional, Belo Horizonte, ano 4, n. 16, p. 77-106, abr./jun. 2004 
expressão "détournement de pouvoir", para caracterizar certos desvios de poder de polícia conferidos a Administração, que o agente administrativo "cometía cumpliendo un acto de su competência y siguiendo las formas prescritas por la legislación”, isto é, “usa de su poder discrecional para um caso y por motivos distintos de aquellos en relación a los cuales tal poder le habia sido conferido." 14

Esse conceito foi ampliado por Laferrière, ${ }^{15}$ na primeira edição de sua obra fundamental "Traité de la Juridiction Administrative el des Recours Contentieux":

La desviación de poder constituye pues um abuso del mantado que el administrador há recibido. El que lo comete adopta, bajo uma falsa aparencia legalidad, decisiones que no le atañen y que están así, incursos e una especie de incompetencia, sino por las prescriciones que imponem, sí, al menos, por el fin que persiguen.

\section{Maurice Hauriou define o desvio de poder como: ${ }^{16}$}

El hecho de uma autoridad administrativa que, cumpliendo un acto de su competência, observando las formas prescritas y sin cometer ninguna violación de ley, usa de su poder com um fin y por motivos distintos a aquellos por los cuales se le ha conferido el poder, es decidir, distintos al bien del servicio."

De modo semelhante, André de Laubadére define: ${ }^{17}$

Existe desviación de poder cuando una autoridad administrativa cumple regularmente un acto de su competencia pero em vista de um fin distinto a aquél por el cual podía ser cumplido el acto.

\section{J.N. Auby e R. Drago ${ }^{18}$ não destoam do que foi dito:}

La desviación de pode es um vicio del acto administrativo que tiene lugar cuando una autoridad administrativa ha venido utilizando voluntariamente sus poderes con um fin distinto a aquél por el cual la han sido conferidos.

O motivo ${ }^{19}$ e o fim limitam o ato administrativo discricionário, que deverá perquirir esses requisitos para conseguir manter-se eficaz para o direito administrativo, não podendo ser baixado em desconformidade com

\footnotetext{
${ }^{14}$ AUCOC, Leon. Conferences sur l'Administration et le Droit Administratif. Paris: Dunad Editeur, p. 467.

15 LAFERRIÈRE. Traité de la Juridiction Administrative el des Recous Contentieux. 2. ed. Paris, 1896, p. 581.

${ }^{16}$ HAURIOU, Maurice. Precis Detroit Administratif. 9 émé ed. Paris, p. 508.

${ }^{17}$ LAUBADÉRE, André de. Traité Élémentaire de Droit Administratif. Paris, 1957, p. 681.

${ }^{18}$ AUBY, J.N.; DRAGO, R. Traité de Contentieux Administratif. Paris, 1962, p. 84.
} 
os princípios constitucionais.

Esse conceito foi adotado por todos os países que marcham sob o manto do direito, visto que o ato administrativo, mesmo o discricionário, não é uma "caixa preta", onde os critérios e os seus objetivos ficam imunes à fiscalização do Judiciário. Pelo contrário, a atual fase do direito administrativo exige que o agente público paute seus atos nos princípios e as normas constitucionais, visando atingir os objetivos traçados pelo Constituinte.

Assim, nasceu do direito administrativo francês, acompanhado pelo mundo civilizado, a certeza da necessidade de se controlarem os atos adminis-trativos, inclusive os discricionários, que sempre deverão estar condicionados a um interesse público legítimo, ou seja, baixado sob a couraça da legalidade.

Buscou o direito administrativo controlar o Poder Público, para que o ato discricionário não fique imune à aferição de sua legalidade: "Em outros termos: a discricionariedade não pode ser exercida nem contra a finalidade nem mesmo sem ela, apenas, em favor dela." ${ }^{20}$

Mesmo os atos discricionários deverão estar lastreados em competência, forma e finalidade, para suportar o confronto com a lei. A liberdade que a lei confere é quanto ao objetivo e à motivação do ato, condicionados, também, a finalidade e ao interesse público. ${ }^{21}$

Quanto a outra espécie do ato administrativo, os classificados pela doutrina como vinculados, prende-se a cinco elementos: competência, forma, finalidade, motivo e objeto.

Quando o ato é vinculado, ficam mais evidentes estes elementos, facilitando o controle judicial.

Sendo certo que, tanto o ato administrativo vinculado, ${ }^{22}$ como o discricionário, ${ }^{23}$ não podem se distanciar dos princípios constitucionais, especialmente os que vêm estabelecidos no caput do art. 37 da CF, em face

\footnotetext{
19 "Cabe ao Poder Judiciário apreciar a realidade e a legitimidade dos motivos em que se inspira o ato discricionário da Administração. O exercício do Poder de Polícia está sujeito a censura Judiciário." (BRASIL. Supremo Tribunal Federal. Rel. Min. Hahnemann Guimarães, RE n 17.126/MG, 2a T., Ementário no 77-01, p. 209.

${ }^{20}$ FIGUEIREDO NETO, Diogo de. Legitimidade e Discricionariedade. Forense, 1998, p. 34.

21 "A particularidade dos atos discricionários consiste em que, embora competência, forma e finalidade continuem sendo elementos vinculados, a lei admite, de forma expressa ou em decorrência do emprego de conceitos indeterminados, alguma liberdade de decisão ao administrador quando a motivação e ao objeto. Nessas hipóteses é que se encontram o chamado poder discricionário da Administração Pública". (BARROSO, Luis Roberto. Temas de Direito Constitucional. Renovar, 2003, t. II, p. 363).

22 "Controle jurisdicional de ato administrativo vinculado. O exame, pelo Poder Judiciário, de sua legalidade, compreende, que os aspectos formais, quer os materiais, nestes incluindo os motivos e pressupostos que o determinaram." (BRASIL. Supremo Tribunal Federal. Rel. Min. Xavier de Albuquerque, Embargos em RE $n^{\circ}$ 75.421/BA, DJ 1 out. 1976).

"Funcionário público. Demissão. Controle jurisdicional do ato administrativo vinculado. O exame, pelo Judiciário,

de sua legalidade, compreende aspectos formais e materiais, incluindo-se nestes a existência dos pressupostos, $\quad$ p o r l e i , q u e o determinaram." (BRASIL. Supremo Tribunal Federal. Rel. Min. Rodrigues Alkmin, RE 'no 81.523/PA,
}

A \& C R. de Dir. Administrativo e Constitucional, Belo Horizonte, ano 4, n. 16, p. 77-106, abr./jun. 2004 
da constitucionalização das normas da Administração Pública.

\section{O Supremo Tribunal Federal e o controle do abuso de poder administrativo}

O STF,como guardião final da CF, deixou assente em sua jurisprudência que o controle dos excessos ou abusos praticados por outros Poderes da República não ofende a divisão funcional do poder, a que alude o art. $2^{\mathrm{o}}$ da Carta Política.

O princípio da separação de poderes não é suficiente para obstar que o Poder Judiciário assegure o cumprimento das franquias constitucionais.

Aliás, esta é a tônica do STF, quando da decisão plenária do MS n ${ }^{\circ}$ 23.452-1/RJ, impetrado contra ato coator do Presidente de determinada Comissão Parlamentar de Inquérito:

\section{(...) O CONTROLE JURISDICIONAL DE ABUSOS PRATICADOS POR CO- MISSÃO PARLAMENTAR DE INQUÉRITO NÃO OFENDE O PRINCÍPIO DA SEPARAÇÃO DE PODERES:}

- A essência do postulado da divisão funcional do poder, além de derivar da necessidade de conter os excessos dos órgãos que compõem o aparelho de Estado, representa o princípio conservador das liberdades do cidadão e constitui o meio mais adequado para tornar efetivos e reais os direitos e garantias proclamados pela Constituição.

Esse princípio, que tem assento no art. $2^{\circ}$ da Carta Política, não pode constituir e nem qualificar-se como um inaceitável manto protetor de comportamentos abusivos e arbitrários, por parte de qualquer agente do Poder Público ou de qualquer instituição estatal.

- O Poder Judiciário, quando intervém para assegurar as franquias constitucionais e para garantir a integridade e a supremacia da Constituição, desempenha, de maneira plenamente legítima, as atribuições que lhe conferiu a própria Carta da República.

O regular exercício da função jurisdicional, por isso mesmo, desde que pautado pelo respeito à Constituição, não transgride o princípio da separação de poderes.

Desse modo, não se revela lícito afirmar, na hipótese de desvios jurídico-constitucionais nas quais incida uma Comissão Parlamentar de Inquérito, que o exercício da atividade de controle jurisdicional possa traduzir situação de ilegítima interferência na esfera de outro Poder da República.

\footnotetext{
23 "Desvio de Poder pode ser aferido pela ilegalidade explícita (frontal ofensa ao texto de lei) ou por censurável comportamento do agente, valendo-se de competência própria para atingir finalidade alheira àquela abonada pelo interesse público, em seu maior grau de compreensão e interesse público amplitude. A análise da motivação da do ato administrativo, revelando um mau uso da motivação do ato administrativo, revelando um mau uso

competência e finalidade despojada de superior interesse público, defluindo o vício constitutivo, o ato aflige a moralidade administrativa, merecendo inafastável desfazimento." (BRASIL. Superior Tribunal de Justiça. Rel. Min.
}

A \& C R. de Dir. Administrativo e Constitucional, Belo Horizonte, ano 4, n. 16, p. 77-106, abr./jun. 2004 
Em seu voto condutor, o Min. Celso de Mello assim averbou:

Com efeito, o sistema constitucional brasileiro, ao consagrar o princípio da limitação de poderes, teve por objetivo instituir modelo destinado a impedir a formação de instâncias hegemônicas de poder no âmbito do Estado, em ordem a neutralizar, no plano político-jurídico, a possibilidade de denominação institucional de qualquer dos Poderes da República sobre os demais órgãos da soberania nacional.

Com a finalidade de impedir o exercício abusivo das prerrogativas estatais pudesse conduzir as práticas que transgredissem o regime das liberdades públicas e que sufocassem, pela opressão do poder, os direitos e garantias individuais, atribui-se ao Poder Judiciário a função eminente de controlar os excessos cometidos por qualquer das esferas governamentais.

É da lavra do mesmo Relator, Min. Celso de Mello, a seguinte decisão, ${ }^{24}$ desta feita nos autos do MS no 23.585:

Cumpre não perder de perspectiva que, no regime constitucional que consagra o Estado Democrático de Direito, as decisões políticas emanadas de qualquer das casas do Congresso Nacional, na medida em que delas derivem conseqüências de ordem jurídica, estão sujeitas ao controle jurisdicional; desde que tomadas com inobservância da Constituição e das leis. Quando estiver em questão, portanto, a necessidade de impor por respeito à ordem constitucional, a invocação do princípio da separação de poderes não terá a virtude nem de impedir o controle judicial e nem de exonerar qualquer das Casas do Congresso Nacional do dever de observar o que prescreve a Lei Fundamental da República.

Por sua vez, mantendo-se eficaz o posicionamento declinado, o Excelso Sodalício, no Ag. $\mathrm{n}^{\mathrm{o}} 17.1342-0,{ }^{25}$ decidiu:

Concurso - Correção de Prova - Princípio Político Constitucional da Separação da Independência e Harmonia dos Poderes. Longe fica contrariar o disposto no art. $2^{\circ}$ da Carta Política da República provimento judicial que, a partir da premissa sobre a má-vontade da banca examinadora na correção da prova manuscrita, considerada a caligrafia do candidato, assenta a improcedência dos erros apontados.

Ultrapassado este ponto, onde se verifica que, quando o STF exerce o controle da legalidade de atos administrativos emanados dos Poderes Executivo ou Legislativo não invade a esfera da separação de poderes a que alude o art. $2^{\circ}$ da CF, é de se registrar que, quando verifica excesso ou abuso de poder, a Excelsa Corte, utilizando-se do seu poder/dever, vem coibindo

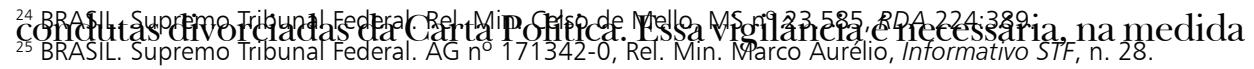


ideal, colocando o tempero constitucional como o melhor ingrediente da receita.

Funciona, o STF, dessa forma, não como um intruso no Poder alheio, e sim como o fiel depositário das garantias constitucionais pelas quais tanto clama a sociedade.

Nesse sentido, funcionou o controle jurisdicional do desvio de poder na análise de requisitos subjetivos para edição de Medidas Provisórias, onde o Plenário do STF, em decisão unânime, deferiu o pedido de medida cautelar em sede Ação Direta de Inconstitucionalidade, para suspender os efeitos do texto analisado, por entender que na hipótese sub examem inexistiriam os requisitos de relevância e urgência exigidos pela Constituição Federal para sua edição pelo Presidente da República. Esse julgamento cautelar teve como objeto o art. $4^{\mathrm{o}}$, da MP $\mathrm{n}^{\mathrm{o}}$ 1632-1, de 09.04.98, que ampliava o prazo de decadência de dois para cinco anos, quando proposta a ação rescisória pela União, Estados, DF ou os Municípios e suas respectivas autarquias e fundações públicas (art. $4^{\circ}$, caput) e criava, em favor dos citados entes de direito público, uma nova hipótese de rescindibilidade dos julgados. Entendeu o STF, ${ }^{26}$ portanto, que era flagrante a ausência de relevância e urgência, consignando:

Medida Provisória: excepcionalidade da censura jurisdicional da ausência dos pressupostos de relevância e urgência à sua edição: raia, no entanto, pela irrisão a afirmação de urgência para as alterações questionadas à disciplina legal da ação rescisória quando, segundo a doutrina e a jurisprudência, sua aplicação à rescisão de sentenças já transitadas em julgado, quanto a uma delas a criação de novo caso de rescindibilidade - é pacificamente inadmissível e quanto à outra a- a ampliação do prazo de decadência — é pelo menos duvidosa.

Da mesma forma, o $\mathrm{STF}^{27}$ concedeu medida liminar entendendo que:

... a edição de medida provisória faz-se no campo da excepcionalidade. Leitura eqüidistante do artigo 62 da Carta Política revela a necessidade de concorrerem requisitos, a saber: a relevância e a urgência do trato da matéria de forma excepcional, ou seja, pelo próprio Presidente da República em detrimento da atuação dos representantes do povo e dos Estados, ou seja, das Câmaras Legislativas. Pois bem, na espécie, não estão presentes estas condições, no que modificada a lei que já se encontrava em vigor desde 1992.

Estes precedentes declinados são de suma importância, pois a edição

${ }^{26}$ BRASIL. Supremo Tribunal Federal. Rel. Min. Sepúlveda Pertence, ADIN nº 1.753-1/DF, Medida Liminar, Pleno, DJ 12 jun. 1998, p. 51.

27 BRASIL. Supremo Tribunal Federal. Rel. Min. Marco Aurélio, ADIN no 1.849-0/DF, Medida Liminar, DJ 4 ago. 1998.

A \& C R. de Dir. Administrativo e Constitucional, Belo Horizonte, ano 4, n. 16, p. 77-106, abr.jun. 2004 
de Medidas Provisórias se abriga na esfera de discricionariedade do Chefe do Executivo (Presidente da República), desde que presentes os requisitos de relevância e urgência. Até as duas decisões acima transcritas, entendia o Pretório Excelso competir, de forma exclusiva e discricionária, ao Presidente da República, no momento da edição das Medidas Provisórias, a análise se a situação fática realmente enquadra-se no conceito de relevância e urgência. Alterando o seu entendimento, o STF, passou a entender pela possibilidade excepcional de controle jurisdicional da interpretação dos requisitos constitucionais, quando ficar caracterizado que a MP editada não contém em sua essência os requisitos básicos para sua existência: relevância e urgência.

Este exemplo é bastante salutar, pois ficou consignado, para sempre, que compete ao Judiciário penetrar no ato administrativo, para confrontá-lo com o que vem estatuído na Constituição Federal.

Em abono ao que foi dito, e comprovando a ampliação do controle jurisdicional em relação a atos discricionários, pode-se citar outra expressiva passagem do STF, quando do julgamento do RE $\mathrm{n}^{\mathrm{o}} 167.137 / 70,{ }^{28}$ onde estava sendo discutido o abuso da discricionariedade para análise dos requisitos subjetivos para nomeações políticas. Esses requisitos subjetivos, tais como: "notório saber jurídico", "notórios conhecimentos jurídicos, econômicos, financeiros e contábeis ou de administração pública”, "reputação ilibada", "idoneidade moral", haviam sido desprezadas pelo Chefe do Executivo quando da nomeação de Conselheiro de Tribunal de Contas de determinado Estado. Entendeu o STF nesse julgamento ${ }^{29}$ que, apesar de exigir discricionariedade do Poder Executivo para analisar esses requisitos, há a "necessidade de um mínimo de pertinência entre as qualidades intelectuais dos nomeados e o ofício a desempenhar".

Visa esse controle estancar o abuso de poder do ato discricionário, que poderá vir desviado por finalidades pessoais, contrárias ao interesse público. Caso típico do que foi afirmado é quando o administrador promove determinada remoção de servidor público, para puni-lo ou demonstrar poder sobre os demais agentes públicos, deixando de revelar os motivos que precedem o ato.

É da lavra do eminente Min. Marco Aurélio ${ }^{30}$ o repúdio a esta conduta:

\footnotetext{
${ }^{28}$ BRASIL. Supremo Tribunal Federal. Rel. Min. Paulo Brossard, RE no 167.137/TO, 2a T., DJ 25 nov. 1994, p. 32.312.

${ }^{29}$ BRASIL. Supremo Tribunal Federal. Rel. Min. Celso de Mello, MS nº 23.452-1/RJ, Pleno, ementário nº 19901, DJ 12 maio 2000.
}

A \& C R. de Dir. Administrativo e Constitucional, Belo Horizonte, ano 4, n. 16, p. 77-106, abr./jun. 2004 
Longe fica de vulnerar o art. 6º , parágrafo único, da Constituição de 1969 acórdão em que afastando ato administrativo, praticado com abuso de poder, no que revelou remoção de funcionário sem a indicação dos motivos que estariam a respalda-la. Na dicção sempre oportuna de Celso Antônio Bandeira de Mello, mesmo nos atos discricionários não há margem para que a administração atue com excessos ou desvio ao decidido, competindo ao Judiciário a glosa cabível.

Funcionando como repressor dos excessos cometidos, o STF brecou o exercício abusivo das prerrogativas estatais, notadamente na autuação de Comissão Parlamentar de Inquérito, que transgrediu os limites eleitos pela lei, abusando de suas prerrogativas:

\section{O CONTROLE DO PODER CONSTITUI UMA EXIGENAIA DE ORDEM POLÍTICA-JURÍDICA ESSENCIAL AO REGIME DEMOCRÁTIVO.}

- O sistema Constitucional brasileiro, ao consagrar o princípio da limitação de poderes, teve por objetivo instituir modelo destinado a impedir a formação de instâncias hegemônicas de poder no âmbito do Estado, em ordem a neutralizar, no plano político-jurídico, a possibilidade de dominação institucional de qualquer dos Poderes da República sobre os demais órgãos da soberania nacional.

Com a finalidade de obstar que o exercício abusivo das prerrogativas estatais possa conduzir as práticas que transgridam o regime das liberdades públicas e que sufoquem, pela opressão do poder, os direitos e garantias individuais, atribui-se, ao Poder Judiciário, a função eminente de controlar os excessos cometidos por qualquer das esferas governamentais, inclusive aqueles praticados por Comissão Parlamentar de Inquérito, quando incidir em abuso de poder ou em desvios inconstitucionais, no desempenho de sua competência investigatória.

OS PODERES DAS COMISSÕES PARLAMENTARES DE INQUÉRITO, EMBORA AMPLOS, NÃO SÃO ILIMITADOS E NEM ABSOLUTOS.

- Nenhum dos Poderes da República está acima da Constituição. No regime político que consagra o Estado Democrático de direito, os atos emanados de qualquer Comissão Parlamentar de Inquérito, quando praticados com desrespeito à Lei Fundamental, submete-se ao controle jurisdicional (CF, art. $5^{\circ}$, XXXV). As Comissões Parlamentares de Inquérito não têm mais poderes do que aqueles que lhes são outorgados pela Constituição e pelas leis da República.

- É essencial, reconhecer que os poderes das Comissões Parlamentares de Inquérito - precisamente porque não são absolutos sofrem as restrições impostas pela Constituição da República e encontram limites nos direitos fundamentais do cidadão, que só podem ser afetados nas hipóteses e na forma que a Carta Política estabelecer. DOUTRINA. PRECEDENTES. LIMITAÇÕES AOS PODERES INVESTIGATÓRIOS DA COMISSÃO PARLAMENTAR DE INQUÉRITO.

- A Constituição da República, ao outorgar às Comissões Parlamentares de Inquérito "poderes de investigação próprios das autoridades judiciais" (art.

\footnotetext{
${ }^{30}$ BRASIL. Supremo Tribunal Federal. Rel. Min. Marco Aurélio, RE n 131.661/ES, 2a T., DJ 17 nov. 1995, p. 39.209.
}

A \& C R. de Dir. Administrativo e Constitucional, Belo Horizonte, ano 4, n. 16, p. 77-106, abr./jun. 2004 
$\left.58, \S 3^{\circ}\right)$, claramente delimitou a natureza de suas atribuições institucionais, restringindo-as, unicamente, ao campo da indagação probatória, com absoluta exclusão de quaisquer outras prerrogativas que se incluem, ordinariamente, na esfera de competência dos magistrados...

O eminente Min. Celso de Mello, ${ }^{31}$ do alto da sua envergadura jurídica, arrematou:

Não se deve reconhecer que a CPI - qualquer que seja o fato determinado que tenha justificado a sua instauração — não pode exceder, sob pena de incidir em abuso de poder, os parâmetros que delimitam, em nosso ordenamento positivo, a extensão dos seus poderes investigatórios. Esses possíveis desvios jurídicos são reconhecidos por nossa melhor doutrina, que, por referir a atuação ultra vises dos órgãos de investigação parlamentar e ao admitir a conseqüência possibilidade de seu controle jurisdicional, observa (José Alfredo de Oliveira Baracho, "Teoria Geral das Comissões Parlamentares - Comissões Parlamentares de Inquérito", p. 147, 1988, Forense, verbis:

"As Comissões Parlamentares de Inquérito, no exercício de suas atribuições, não podem exercê-las com abuso de poder. A competência investigatória tem limites na Constituição e nas leis, sendo passíveis de controle jurisdicional, através do remédio do habeas corpus, desde que a atuação dos mesmos venha a acarretar lesão atual ou iminente à liberdade de locomoção física. Será utilizável o Mandado de Segurança, na violação de direito líquido e certo.”

Comungando com a evolução constitucional doutrinária e jurisprudencial, o STF freqüentemente coloca nos "trilhos" o exercício do poder disciplinar, quando os abusos são identificados de forma cristalina. Cessa, assim, os Poderes de Comissão Disciplinar quando o ato administrativo hostilizado se distancia do que vem estatuído no art. 37, da CF.

A respeito do que foi dito, o Colendo Tribunal ${ }^{32}$ sentenciou:

1. A Constituição Brasileira de 1988 prestigiou os instrumentos de tutela jurisdicional das liberdades individuais ou coletivas e submeteu o exercício do poder estatal - como convém a uma sociedade democrática e livre - ao controle do Poder Judiciário. Inobstante estruturalmente desiguais, as relações entre o estado e os indivíduos processam-se, no plano de nossa organização constitucional, sob o império estrito da lei. a rule of law, mais do que um simples legado histórico-cultural, constitui, no âmbito do sistema jurídico vigente no Brasil, pressuposto conceitual do estado democrático de direito e fator de contenção do arbítrio daqueles que exercem o poder.

É preciso evoluir, cada vez mais, no sentido da completa justiciabilidade de toda e qualquer fiscalização judicial. A progressiva redução e eliminação dos círculos de imunidade do poder há de gerar, como expressivo efeito conseqüencial, a ${ }^{31}$ BRASIL. Supremo Tribunal Federal. REL. Min. Celso de Mello, MS nº 23.452-1/RJ, Pleno, Ementário n 1990-1, DJ 12 maio 2000.

A \& C R. de Dir. Administrativo e Constitucional, Belo Horizonte, ano 4, n. 16, p. 77-106, abr./jun. 2004 
interdição de seu exercício abusivo.

O mandado de segurança desempenha, nesse contexto, uma função instrumental do maior relevo. A impugnação judicial de ato disciplinar legitima-se em face de três situações possíveis, decorrentes (1) da incompetência da autoridade, (2) da inobservância das formalidades essenciais e (3) da ilegalidade da sanção disciplinar. A pertinência jurídica do mandado de segurança, em tais hipóteses, justifica a admissibilidade do controle jurisdicional sobre a legalidade dos atos punitivos emanados da Administração Pública no concreto exercício do seu poder disciplinar.

Por igual, quando é verificado o cerceamento de defesa em inquérito administrativo, onde se constata desmandos administrativos perpetrados por Comissões de Inquérito que insistem em reeditar o abolido sistema da "verdade sabida", o STF tem determinado a recondução de servidor demitido, por não lhe ter sido dada a chance de ouvir suas testemunhas. Em síntese, por entender que há ofensa à regra do due process of law, contido no art. $5^{\circ}$, LV, da CF, o STF anula o procedimento administrativo desde a sua origem, com a reintegração ${ }^{33}$ do servidor público demitido, como se verifica dos seguintes arestos:

Mandado de Segurança. Funcionário Público. Demissão. Cerceamento de defesa. Vício consistente em não haverem sido ouvidas, pela Comissão de Inquérito, as testemunhas da defesa, e que, não obstante assinalado pela Secretaria de Administração Federal, não impediu a aplicação da drástica pena. nulidade do processo. recondução do Impetrante ao seu cargo, onde aguardara a renovação do procedimento disciplinar. Segurança parcialmente deferida. ${ }^{34}$

Mandado de Segurança. Demissão a bem do serviço público. Incompetência do Ministério condutor da investigação. Cerceamento de defesa. Mandado de Segurança impetrado por servidor autárquico demitido por Decreto Presidencial a bem do serviço público. Incompetência do Ministério a que vinculada a autarquia para conduzir o procedimento disciplinar, frente a autonomia que ostenta a autarquia, por sê-lo, para tanto. Ocorrência de cerceamento de defesa consistente em indeferimento de prova baseado tão-só na letra da lei. Mandado de Segurança deferido, com a anulação do procedimento disciplinar e, conseqüentemente, do ato demissório. ${ }^{35}$

Demissão. Processo administrativo: indeferimento de prova testemunhal oportunamente requerida: exigência de motivação (L. 8.112/90, art. 156, PAR. 1.): nulidade da demissão E do processo, a partir do indeferimento imotivado da prova. ${ }^{36}$

\footnotetext{
32 BRASIL. Supremo Tribunal Federal. Rel. Min. Celso de Mello, MS n² 20.999/DF, DJ 25 maio 1990, p. 4.605.

33 "A demissão do funcionário, como ato vinculado, é passível de controle jurisdicional para aferição da existência de abuso de poder ou de ilegalidade." (BRASIL. Supremo Tribunal Federal. Rel. Min. Djaci Falcão, MS n 17.148, Pleno, RDA 92:184)
}

A \& C R. de Dir. Administrativo e Constitucional, Belo Horizonte, ano 4, n. 16, p. 77-106, abr./jun. 2004 
Nessa vertente, quando determinada Comissão Disciplinar não prestigia a regra do due process of law, colide com outros princípios legais, dentre eles o da impessoalidade, norma contida no art. 37 da CF.

Também se manifesta de forma sólida e contundente o STF quanto a quebra indiscriminada de sigilo de dados dos investigados.

Isto porque, o direito a privacidade, a que alude o art. $5^{\circ}$, X e XII, da CF, é verificado também pelo respeito da manutenção do sigilo de dados.

Vulgarizá-lo, com a quebra de sigilo indiscriminadamente, sem uma justa causa, seria o mesmo que engessar o direito a intimidade do cidadão.

Sem justo motivo, onde cabalmente é demonstrada a necessidade da quebra dos sigilos fiscal, bancário e telefônico, o ato praticado se afigura como abusivo, demonstrando uma índole ilegal.

Exatamente neste sentido, está a visão do STF:

As Comissões Parlamentares de Inquérito, no entanto, para decretarem, legitimamente, por autoridade própria, a quebra de sigilo bancário, do sigilo fiscal e/ou do sigilo telefônico, relativamente a pessoas por elas investigadas, devem demonstrar, a partir de meros indícios, a existência concreta de causa provável que legitime a medida excepcional (ruptura da esfera de intimidade de quem se acha sob investigação), justificando a necessidade de sua efetivação no procedimento de ampla investigação dos fatos determinados que deram causa à instauração de inquérito parlamentar, sem prejuízo de ulterior controle jurisdicional dos atos em referência (CF, art. 5, XXXV).

- As deliberações de qualquer Comissão Parlamentar de Inquérito, à semelhança do que também ocorre com as decisões judiciais (RTJ 140/514), quando destituídas de motivação, mostram-se írritas e despojadas de eficácia jurídica, pois nenhuma medida restritiva de direitos pode ser adotada pelo Poder Público, sem que $o$ ato que o decreta seja adequadamente fundamentado pela autoridade estatal. ${ }^{37}$

COMISSÃO PARLAMENTAR DE INQUÉRITO - QUEBRA DE SIGILO — AUSÊNCIA DE INDICAÇÃO CONCRETA DE CAUSA PROVÁVEL — NULIDADE DA DELIBERAÇÃO PARLAMENTAR — MANDADO DE SEGURANÇA CONCEDIDO.

A QUEBRA DE SIGILO NÃO PODE SER UTILIZADA COMO INSTRUMENTO DE DEVASSA INDISCRIMINADA, SOB PENA DE OFENSA À GARANTIA CONSTITUCIONAL DA INTIMIDADE.

- A quebra de sigilo, para legitimar-se em face do sistema jurídico-constitucional

\footnotetext{
${ }^{34}$ BRASIL. Supremo Tribunal Federal. MS n 21.815-DF, TP, julgado em 3/3/94, Rel. Min. Ilmar Galvão, RTJ 153/ 831.

${ }^{35}$ BRASIL. Supremo Tribunal Federal. MS no 21.579-DF, TP, v.u. 25.03.93, Rel. Min. Francisco Rezek. RTJ 146/ 535.

${ }^{36}$ BRASIL. Supremo Tribunal Federal. MS n 21.402-AL TP, v.u. 5.03.93, Rel. Min. Sepúlveda Pertence, RTJ 150/ 102.
}

A \& C R. de Dir. Administrativo e Constitucional, Belo Horizonte, ano 4, n. 16, p. 77-106, abr./jun. 2004 
brasileiro, necessita apoiar-se em decisão revestida de fundamentação adequada, que encontre apoio concreto em suporte fático idôneo, sob pena de invalidade do ato estatal que a decreta.

A ruptura da esfera de intimidade de qualquer pessoa - quando ausente a hipótese configuradora de causa provável — revela-se incompatível com o modelo consagrado na Constituição da República, pois a quebra de sigilo não pode ser manipulada, de modo arbitrário, pelo Poder Público ou por seus agentes. Não fosse assim, a quebra de sigilo converter-se-ia, ilegitimamente, em instrumento de busca generalizada, que daria, ao Estado - não obstante a ausência de quaisquer indícios concretos - o poder de vasculhar registros sigilosos alheios, em ordem a viabilizar, mediante a ilícita utilização do procedimento de devassa indiscriminada (que nem mesmo o Judiciário pode ordenar), o acesso a dado supostamente impregnado de relevo jurídico-probatório, em função dos elementos informativos que viessem a ser eventualmente descobertos.

A FUNDAMENTAÇÃO DA QUEBRA DE SIGILO HÁ DE SER CONTEMPORÂNEA À PRÓPRIA DELIBERAÇÃO LEGISLATIVA QUE A DECRETA.

- A exigência de motivação - que há de ser contemporânea ao ato da Comissão Parlamentar de Inquérito que ordena a quebra de sigilo - qualifica-se como pressuposto de validade jurídica da própria deliberação emanada desse órgão de investigação legislativa, não podendo ser por este suprida, em momento ulterior, quando da prestação de informações em sede mandamental. Precedentes. ${ }^{38}$

- As Comissóes Parlamentares de Inquérito podem decretar a quebra de sigilo bancário, sigilo fiscal e telefônico para suas investigações.

- $\mathrm{O}$ ato com essa finalidade deve, porém, ser adequadamente motivado.

- A ausência de motivação razoável permite a concessão de medida liminar em Mandado de Segurança. ${ }^{39}$

Entendo presentes os pressupostos do fumus boni iuris e do periculum in mora, os impetrantes requerem a concessão da medida liminar; esta no sentido de sustar a execução das medidas de quebra dos sigilos bancário, fiscal dos impetrantes e a expedição de ofícios ao Excelentíssimo Senhor Secretário da Receita Federal e ao Excelentíssimo Senhor Presidente do Banco Central, comunicando a concessão da medida liminar supra-referida (fls. 04/05).

Na decisão que proferi no MS no 23.843-RJ, impetrado por Carlos Augusto Saade Montenegro, escrevi:

“(..)

A Jurisprudência do Supremo Tribunal Federal é no sentido de que as Comissões Parlamentares de Inquérito, para decretar a quebra do sigilo bancário, fiscal e ou telefônico de pessoas por elas investigadas, têm que fundamentar a sua decisão, tal como ocorre com as autoridades judiciais, indiciando a necessidade objetiva da medida.

Indico, por exemplo, o decidido nos MMSS 23.452-RJ, Relator o Ministro Celso

\footnotetext{
${ }^{37}$ BRASIL. Supremo Tribunal Federal. Rel. Min. Celso de Mello, MS nº 23.452-1/RJ, Pleno, Ementário n $1990-$ 1, DJ 12 maio 2000.

${ }^{38}$ BRASIL. Supremo Tribunal Federal. Rel. Min. Celso de Mello, MS nº 23.851-8/DF, Pleno, Ementário n $2074-$

2, DJ de 2074-2, DJ 21 jun. 2002
}

A \& C R. de Dir. Administrativo e Constitucional, Belo Horizonte, ano 4, n. 16, p. 77-106, abr./jun. 2004 
de Mello (Plenário 16/09/99; DJ de 12/05/2000) e 23.619-DF, Relator o Ministro Octávio Gallotti (Plenário, 4/5/2000), DJ de 7/12/2000).”

Ora, se as Comissões Parlamentares de Inquérito têm poderes de investigação próprios das autoridades judiciais (C.F., art. 58, § $3^{\circ}$ ), têm, também, as mesmas obrigações destas. E estabelece a Constituição, no art. 93, IX, que as decisões jurídicas serão fundamentadas, sob pena de nulidade.

Assim posta a questão, tenho como confirmados, no caso, os requisitos do fumus boni iuris e do periculum in mora. ${ }^{40}$

Até mesmo em uma rescisão pura e simples de ato administrativo, sem motivação, que já havia produzido efeitos para o administrado, foi considerado como abuso: "A rescisão pura e simples de ato administrativo, que já produziu efeitos, constitui-se abuso de poder."41

Seria interminável o rol de citações dos v. acórdãos do STF que abonam a compreensão universalmente aceita de que o respeito à legalidade e aos princípios constitucionais é condição essencial de validade dos atos administrativos, estando apto o Poder Judiciário a exercer o seu fiel papel de defensor da Constituição.

\section{Desvio de poder legislativo}

O Poder Legislativo é exercido pelo Congresso Nacional, composto da Câmara de Deputados e do Senado Federal (art. 44 da CF).

As funções típicas do Poder Legislativo são legislar e fiscalizar, sendo que na primeira hipótese, a Constituição prevê regras de processo legislativo a ser seguido pelo Congresso Nacional quando da elaboração de normas jurídicas e, na outra situação, fiscaliza a parte contábil, financeira, orçamentária, operacional e patrimonial do Poder Executivo (art. 70 da CF).

Não resta dúvida de que, nestas situações, os órgãos legislativos são dotados de discricionariedade peculiar à função política que exercem.

Como já sublinhado no início do presente ensaio, a constitucionalização das normas da Administração Pública permite que o Poder Judiciário atribua dose de temperamentos à discricionarieade, incluindo-se neste contexto a pertinente a ato do Poder Legislativo, "ainda que fundado em competência constitucional e formalmente válido." ${ }^{2}$

Nessa vertente, é de se abrirem parênteses para registrar as sempre oportunas palavras do mestre Caio Tácito: ${ }^{43}$

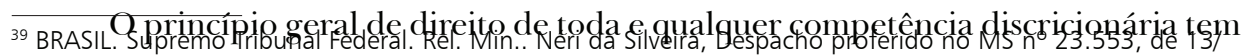
10/99, RDA 218:285.

40 BRASIL. Supremo Tribunal Federal. Rel. Min. Carlos Velloso, Ms n 23.858-5, Medida Liminar, 5/01/2001, RDA 223:250-251.

${ }^{41}$ BRASIL. Supremo Tribunal Federal. Rel. Min. Vilas Boas, Ms n 13.942, RDA 81:206.

A \& C R. de Dir. Administrativo e Constitucional, Belo Horizonte, ano 4, n. 16, p. 77-106, abr./jun. 2004 
como limite a observância da finalidade que lhe é própria, embora historicamente vinculado à atividade administrativa, também se compadece, a nosso ver, com a legitimidade da ação de legislar.

Ocorrendo desvio de poder legislativo, configurado pela inconstitucionalidade da norma, pode o próprio Legislativo anular seus atos, ou caso contrário, o Judiciário estará apto a desfazer a norma jurídica viciada. ${ }^{44}$

O excesso da norma jurídica se verifica quando é confrontada com a Constituição, ou quando não cumpre requisito formal para a sua validade.

O tema do desvio de poder legislativo, segundo Caio Tácito, foi amplamente estudado no direito italiano, e o insigne mestre trouxe a lume, dentre outras, as palavras de Livio Paladin: ${ }^{45}$

A ilegitimidade de todo fim, diverso daquele constitucionalmente previsto, conduz logicamente a configurar-se, no pleno legislativo, aquele vício de causa dos atos administrativos, que é o excesso de poder.

Pois bem, o excesso de poder legislativo se afigura também quando a norma legal editada se distancia da finalidade constitucional que fundamenta e ampara o próprio exercício do legislativo.

É da pena inteligente de J.J. Canotilho ${ }^{46}$ as seguintes observações sobre o "excesso de poder legislativo ou desvio de poder legislativo", quanto aos vícios de mérito:

As hipóteses de vício de mérito conduzem-se, fundamentalmente, as duas categorias: (1) vícios de mérito porque o uso do poder legislativo no sentido de impor determinadas soluções é objectivamente inadmissível perante determinadas circunstâncias, violando-se regras e princípios constitucionais (princípio da igualdade, princípio da proibição do excesso de direitos, liberdades e garantias); (2) vícios de mérito por irrazoabilidade da lei captada através de um conjunto de manifestações (inconseqüência, incoerência, ilogicidade, completo afastamento do senso comum e da consciência ético-jurídica cominatória). Na primeira hipótese, há casos que se entrecruzam com dimensões presentes na segunda hipótese (ex: violação da proibição do excesso).

As hipóteses mais discutíveis são aquelas que os fins da lei ou dos meios utilizados são materialmente falsos. Nestes últimos casos, a falsidade material dos meios e dos fins poderá legitimar um controle mais intenso...

O ilustre publicista lusitano traz aos seus estudos a incorporação de

\footnotetext{
42 TÁCITO, Caio. Desvio de Poder por Atos Administrativos, Legislativos e Jurisdicionais. RDA 228:4.

${ }^{43}$ Apud TÁCITO, Caio, cit. ant., p. 4

44 "Os poderes Legislativo e Executivo podem anular seus próprios atos, quando os considerem inconstitucionais. Entretanto, a palavra derradeira, a respeito, caberá do Poder Judiciário, sempre que oportunamente provocada." (BRASIL. Supremo Tribunal Federal. Rel. Luiz Gallotti, Ms n 7.243, Pleno, 20/01/69, RDA 59:338).

45 PALADIN, Lívio. Osservazioni Sulla Discrezionalitá e Suli Ecesso di Potere del Legislatore Ordinário. Revista Trimestrale di Diritto Pubblico, ano VI, n. 4, out./dez. 1956, p. 993-1.046 apud TÁCITO, Caio, cit. ant., p. 4.
} 
técnica atual sobre o controle dos excessos legislativos.

Isto porque a doutrina e jurisprudência mais moderna enfatizam que, em se tratando de imposição de restrições a determinados direitos, devese indagar não apenas sobre a admissibilidade constitucional da restrição eventualmente fixada (reserva legal), mas também sobre a compatibilidade das restrições estabelecidas com o princípio da proporcionalidade ou razoabilidade, abrigados no artigo inaugural da Constituição Federal, que consagrou nosso país ao status de Estado Democrático de Direito.

Assim, por essa nova orientação, é permitido converter o princípio da reserva legal (Gesetzezvorbehalt) no princípio da reserva legal proporcional (Vorbehalt des verhältnisniössigen Gestzes), pressupondo não só a legitimidade dos meios utilizados e dos fins perseguidos pelo legislador, mas também a adequação desses meios para a convicção dos objetivos pretendidos e a necessidade de sua utilização.

Dessa forma, pelo princípio da razoabilidade da lei, é possível sanar o problema da lei arbitrária, que permite excéss de pouvoir por parte da autoridade legislativa. ${ }^{47}$

De forma pioneira em nosso cenário doutrinário, Suzana de Toledo Barros $^{48}$ advertiu que a lei tem que ser razoável para ser eficaz:

De fato, a responsabilidade de exame da razoabilidade da lei por parte do judiciário constitui importante mecanismo de proteção aos direitos fundamentais, porquanto a total liberdade do legislador para regulamentá-los tornaria pouco eficaz a cláusula de eternidade a que estão submetidos estes direitos em diversas ordens jurídicas, como é o caso da nossa.

Nessa mesma trilha, Linares realça que o princípio da razoabilidade valoriza a lei justa, banindo a norma arbitrária e descompassada com a realidade da Constituição:

En síntesis, lo que alli sostenemos es que la razoabilidad consiste en una valoración jurídica de justicia, por manera que cuando la constitución política del país impone a los cuerpos legislativos el deber de dictar leyes razonables los obliga a dictar leyes justas. ${ }^{49}$

Deve, portanto, o Poder Judiciário, no confronto com a razoabilidade, verificar os abusos ou excessos praticados pelo legislador, quando do seu exercício legal.

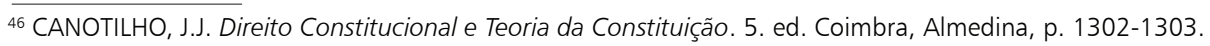

47 "Sem dúvida nenhuma, o espírito de um controle das leis atente à reivindicação de muitas sociedades que,

A \& C R. de Dir. Administrativo e Constitucional, Belo Horizonte, ano 4, n. 16, p. 77-106, abr./jun. 2004 


\section{O Supremo Tribunal Federal e o abuso do poder legislativo}

A interpretação conforme a Constituição permite que o STF corrija os abusos ou desvios legislativos, sem que seja taxado de legislador positivo.

Atento às questões declinadas, o E. Supremo Tribunal Federal tem evoluído seu entendimento, possibilitando a extensão de benefícios, quando se trata de regra constitucional auto-aplicável, que são rigorosamente os casos dos princípios expressos no caput do art. 37, consoante se verifica no Mandado de Segurança n ${ }^{\circ}$. 22307-7/DF, onde o Excelso Pretório estendeu a vantagem de $28,32 \%$ para todos os servidores públicos que não obtiveram o respectivo aumento estipendial, por ter sido afrontada a regra então vigente do inciso $\mathrm{XV}$ do citado art. $37:{ }^{50}$

\section{REVISÃO DE VENCIMENTOS - ISONOMIA.}

A revisão geral da remuneração dos servidores públicos, sem distinção de índices entre servidores públicos civis e militares, far-se-á sempre na mesma data" - inciso X — sendo irredutíveis, sob o ângulo não simplesmente dos servidores públicos civis e militares — inciso XV, ambos no artigo 37 da Constituição Federal.

O princípio da igualdade, seja no enfoque específico dado ao regime jurídico dos servidores públicos, seja aos demais princípios expressos da CF, não deve ser entendido como um dever endereçado somente ao legislador de conceder o mesmo tratamento àqueles que se encontram na mesma situação, mas, também, um dever endereçado ao juiz para que aplique diretamente aos casos levados ao Judiciário a norma constitucional, que, conforme aduziu o STF nesse último e inovador precedente, é norma constitucional auto-aplicável diretamente pelo magistrado e, portanto, dispensa integração legislativa.

Dalmo de Abreu Dallari, ${ }^{51}$ citado pelo v. acórdão em tela, comunga da mesma hóstia, quando afirma que "quando o Poder Judiciário determina que se cumpra a Constituição, ele não está legislando, mas sim, cumprindo as suas funções específicas."

ao longo da experiência histórica, sofreram com o abuso de poder institucionalizado sob as vestes da lei formal." (MATTOS, Mauro Roberto Gomes de. Da Falta de Razoabilidade do Poder Ligiferante que Limita a 30\% Valores de Indébito a serem Compensados Mensalmente. RDA 213:78).

48 BARROS, Suzana de Toledo. O Princípio da Proporcionalidade e o Controle de Constitucionalidade das Leis Restritivas de Direitos Fundamentais. Brasília Jurídica, 1996, p. 26.

49 LINARES, Juan Francisco. Poder Discrecional Administrativo. Buenos Aires: Abeledo-Perrot, 1958, p. 135.

${ }^{50}$ Recurso Ordinário em Mandado de Segurança n 22307-7/DF, Relator Ministro Marco Aurélio, Pleno, DJ 13 jun. 1997, Ementário n 1873-03. 
Na mesma balada, segue a lição de José Afonso da Silva: ${ }^{52}$

Como, então, resolver a inconstitucionalidade da discriminação? Precisamente estendendo o benefício aos discriminados que o solicitarem ao Poder Judiciário, caso por tal caso tal ato é insuscetível de declaração genérica de inconstitucionalidade por via de ação direta.

Fazendo eco a citação anterior, seguem as legendárias palavras de Saavedra Fazardo, invocadas pelo Min. Maurício Corrêa, quando do julgamento do MS n ${ }^{\circ}$. 22.307/DF: "Las leys no puedem darse a entender por si mismas y son cuerpos que reciben el alma y el entendimiento de los jueces, por cuya boca hablan y por cuya pluma se declaram y aplican a casos."

Em outro relevante julgado, o STF, ${ }^{53}$ no AGRRE $n^{\circ}$. 249.454-2/RS, relatado pelo Min. Celso de Mello, se coaduna com o que foi exposto alhures:

(...) A interpretação, qualquer que seja o método hermenêutico utilizado, tem por objetivo definir o sentido e esclarecer o alcance de determinado preceito inscrito no ordenamento positivo do Estado, não se confundido, por isso mesmo, com o ato estatal de produção normativa. Em outras palavras: o exercício de interpretação da Constituição e dos textos legais — por caracterizar atividade típica dos Juizes e Tribunais - não importa em usurpação das atribuições normativas dos demais Poderes da República. Precedente.

O critério da interpretação conforme a Constituição que privilegia a interpretação extensiva da norma legal, em contraposição a interpretações mais restritas está limitado ao "sentido possível" da mesma (e, portanto, este é o limite que circunda a sua própria zona de aplicação, que é o campo da interpretação da norma legal — Larenz).

Com efeito, referido critério restará superado na medida em que se admitir a tutela jurisdicional positiva dos princípios constitucionais não só da igualdade, como e especialmente das normas expressas no caput do art. 37 da CF, pelo que se vislumbraria implícito nesses preceitos constitucionais um comando endereçado ao juiz para que estenda o privilégio àqueles que, inobstante a identidade de situação material, não foram contemplados pelo legislador, cuja hipótese de aplicação reside exatamente na existência de descriminação legal levada à apreciação do Poder Judiciário.

\footnotetext{
${ }^{51}$ DALLARI,Dalmo de Abreu. Regime Constitucional dos Servidores Públicos. 2. ed. São Paulo: Revista dos Tribunais, p. 65.

52 SILVA,José Afonso da. Curso de Direito Constitucional Positivo. 12. ed. São Paulo: Malheiros, p. 222.

${ }^{53}$ BRASIL. Supremo Tribunal Federal. Agravo Regimental em Recurso Extraordinário n. ${ }^{\circ}$ 249.454-2/RS, Rel. Min.

Celso de Mello, $2^{a}$ T., DJ de 26 nov. 1999, ementário nº 1973-15.
}

A \& C R. de Dir. Administrativo e Constitucional, Belo Horizonte, ano 4, n. 16, p. 77-106, abr./jun. 2004 
Em verdade, não fosse o transcrito julgado, o E. Supremo Tribunal Federal há muito já vem reconhecendo a possibilidade de outorgar benefícios e reconhecer direitos, in casu cita-se, como exemplo, a imunidade, inobstante a inexistência de lei, conforme se observa no julgado abaixo colacionado:

\section{MANDADO DE INJUNÇÃO 232-1/RJ}

Mandado de Injunção conhecido, em parte, e, nessa parte, deferido para declarar-se o estado de mora em que se encontra o Congresso Nacional, a fim se que, no prazo de seis meses, adote ele as providências legislativas que se impõem para o cumprimento da obrigação de legislar decorrente do artigo 195, $\S 7^{\circ}$, da Constituição, sob pena de, vencido esse prazo sem que essa obrigação se cumpra, passar o requerente a gozar da imunidade requerida. ${ }^{54}$

Deveras, o princípio é o mesmo, e como pode ser facilmente constatado pela clareza da ementa, a Corte Constitucional reconheceu o direito ao gozo da imunidade, inobstante a Carta Magna vinculá-la a existência de lei a ser editada, litteris:

Art. 195 - A seguridade social será financiada por toda a sociedade, de forma direta e indireta, nos termos da lei, mediante recursos provenientes dos orçamentos da União, dos Estados, do Distrito Federal e dos Municípios, e das seguintes contribuições sociais:

$\S 7^{\circ}$ - São isentas de contribuição para a seguridade social as entidades beneficentes de assistência social que atendam às exigências estabelecidas em lei.

Têm-se, portanto, que, em função da constitucionalização das normas de Administração Pública, o Poder Judiciário amplia, como já dito alhures, o seu leque de controle sobre os atos do Estado. ${ }^{55}$

Não se trata de legislar positivamente, pois compete ao Judiciário interpretar e aplicar as normas legais, em especial os que vêm contidos na Constituição.

Deixando de lado a superada discussão sobre legislador positivo, o STF, cumprindo o seu papel maior de controlador dos atos normativos, quer pelo controle abstrato ou não, vem acolhendo o cabimento do desvio de finalidade como vício de inconstitucionalidade capaz de invalidá-lo ou corrigido o texto normativo defeituoso.

Desde o histórico RE $\mathrm{n}^{\circ} 18.331,{ }^{56}$ onde o saudoso Min. Orosimbo Nonato, funcionando como Relator deixou registrado nos anais do STF que o poder de taxar não pode destruir o contribuinte, aniquilando o

\footnotetext{
${ }^{54}$ BRASIL. Supremo Tribunal Federal. Mandado de Injunção n 232-1/RJ, Relator Ministro Moreira Alves, STF, DJ 27 mar. 1992.
}

A \& C R. de Dir. Administrativo e Constitucional, Belo Horizonte, ano 4, n. 16, p. 77-106, abr./jun. 2004 
desvio de poder do legislativo: "é um poder cujo exercício não deve ir até o abuso, o excesso, o desvio, sendo aplicável, ainda aqui, a doutrina fecunda do détournement de pouvoir".

Seguindo esse posicionamento, pela Representação $\mathrm{n}^{\mathrm{o}} 1.077,{ }^{57} \mathrm{O}$ excesso do poder de taxar foi igualmente repelido pelo STF, sob o mesmo fundamento declinado.

Comentado este último precedente, Seabra Fagundes teve a oportunidade de defender a idéia de que, "a extensão da teoria do desvio de poder originário é essencialmente dirigida aos procedimentos dos órgãos executivos, aos atos do poder legiferante, de maior importância num sistema de Constituição regida, em que se comete ao Congresso a complementação do pensamento Constitucional nos mais variados setores da vida social, econômica e financeira." 58

O princípio em voga voltou a merecer a atenção do STF em inúmeros casos, inclusive na representação $n^{\circ} 930$, quando se discutiu a extensão da liberdade profissional e o sentido da expressão condições de capacidade, tal como encartado no então vigente Art. 153, § 23 da CF, de 1969, sendo que o relator, Min. Rodrigues Alckmin, enfatizou a necessidade de preservarse o núcleo essencial do direito fundamental, ressaltando, contudo, que o legislador ao impor as condições de capacidade, haveria de atender ao "critério da razoabilidade".

E o Min. Moreira Alves, ${ }^{59}$ alargando a configuração constitucional que alberga o princípio da proporcionalidade como um dos elementos robustos que mantém intactos os direitos fundamentais, extraído do princípio da reserva legal ou do princípio do Estado de Direito (Art. $1^{\circ}$ da C.F.), fundamentou sua ótica no sentido do que o princípio sub-examem tem assento constitucional na cláusula do devido processo legal, como sua garantia material.

Por outro prisma, abordando o excesso cometido pelo Legislativo, foi invocado pelo Min. Aliomar Baleeiro, no RE 62.731, ${ }^{60}$ julgado em 07 de abril de 1967, a inconstitucionalidade de Decreto-Lei que impedia que o locatário purgasse a mora do imóvel locado, ficando assim ementado o

acórdão: "No conceito de segurança nacional não se inclui assunto miúdo 55 "A medida que as normas básicas do Direito Administrativo foram constitucionalizadas, alargou-se a possibi lidade de interpretação judicial desses institutos, ampliando-se a ingerência do Poder Judiciário em assuntos tradicionalmente da alçada do administrador." (MORAES, Alexandre de. Constituição do Brasil Interpretada e Legislação Constitucional. São Paulo: Atlas, 2002, p. 770).

${ }^{56}$ Revista Forense.

${ }^{57}$ RTJ, v. 111 , p. 55

${ }^{58}$ Revista Forense, v. 151, p. 549.

A \& C R. de Dir. Administrativo e Constitucional, Belo Horizonte, ano 4, n. 16, p. 77-106, abr./jun. 2004 
de direito privado, tal como a purgação da mora nas locações (...)".

$\mathrm{Na}$ mesma trilha, o Ministro Themístocles Cavalcanti, ${ }^{61}$ aderindo ao voto da maioria da Corte Suprema, vencido o Ministro Relator Thompson Flores, declarou inconstitucional as sanções administrativas contidas nos Decretos-Leis $\mathrm{n}^{\circ} 5$ e 42, de 1937, que impunham discriminação econômica entre os contribuintes, por permitir a admissão de recursos contra autuações fiscais somente daqueles que depositavam administrativamente a quantia devida, ao passo que impedia os recursos dos recorrentes que não caucionassem na esfera administrativa os respectivos valores cobrados.

Como visto, tanto a jurisprudência passada do STF como a atual fiscalizam a atuação do Legislativo e do Executivo, para que esses poderes não cometam atos revestidos de excessos, com flagrante desvio de poder. ${ }^{62}$

Por fim, enfrentando o tema de frente, o Min. Prado Kelly, ${ }^{63}$ ao discorrer sobre lei de organização judiciária na qual era beneficiado determinado servidor, pinçado do contexto geral, não teve dúvida em advertir: "tratava-se de reforma judiciária e a emenda representou um desvio de poder da própria legislatura."

Desse memorável julgamento, participou o Ministro Victor Nunes Leal, ${ }^{64}$ que aderiu ao voto âncora já citado, deixando sua posição nítida "de que podemos exercer controle sobre os desvios de poder da própria legislatura."

A matéria ficou tão sedimentada no Pretório Excelso que mereceu a confecção das Súmulas ns. 20 e 323, que baseiam a interdição de estabelecimento ou apreensão de mercadorias como meio coercitivo para cobrança de tributo.

Assim, pelo princípio sub-examem, é ilegal ato emanado pelo Legislativo que viole preceito constitucional vigente, baixando comando normativo divorciado da finalidade erigida pelo constituinte na Norma Suprema.

Por esse princípio, a Lei $\mathrm{n}^{\circ}$ 9.129/95 se afigura como fruto de um excesso de poder legislativo, contrariando a Constituição Federal ${ }^{65}$ que não permite que a lei ordinária institua empréstimos compulsórios ou crie distinção de contribuintes, visto que nos casos de tributos federais não existe

\footnotetext{
${ }^{59}$ Cf. BRASIL. Supremo Tribunal Federal. ADIN 958, Rel. Min. Marco Aurélio, DJ de 16.05.94, p. 11.675.

${ }^{60}$ RDA 94:169.

${ }^{61}$ RDA 101:217.

62 Sobre a teoria e prática do desvio de poder, o ilustre Professor Caio Tácito discorre com brilhantismo na publicação contida na RDA 117:12.
}

A \& C R. de Dir. Administrativo e Constitucional, Belo Horizonte, ano 4, n. 16, p. 77-106, abr.jun. 2004 
limitação de compensação, podendo o sujeito passivo fazê-la livremente. Não existe razoabilidade no texto legislativo que limita determinados contribuintes, deixando os demais livres de restrições, discriminando-os quanto à espécie e natureza.

Neutralizando excessos de ordem fiscal eventualmente praticados pelo Poder Público, que configura o caráter confiscatório de determinado tributo, o $\mathrm{STF}^{66}$ afastou o aumento da contribuição de seguridade social para os servidores ativos:

CONTRIBUIÇÃO DE SEGURIDADE SOCIAL — SERVIDORES EM ATIVIDADE - ESTRUTURA PROGRESSIVA DAS ALÍQUOTAS: A PROGRESSIVIDADE EM MATÉRIA TRIBUTÁRIA SUPÕE EXPRESSA AUTORIZAÇÃO CONSTITUCIONAL. RELEVO JURÍDICO DA TESE.

- Relevo jurídico da tese segundo a qual o legislador comum, fora das hipóteses taxativamente indicadas no texto da Carta Política, não pode valer-se da progressividade na definição das alíquotas pertinentes à contribuição de seguridade social devida por servidores públicos em atividade. Tratando-se de matéria sujeita a estrita previsão constitucional - CF, art. 153, § $2^{\circ}$, I; art. 153, § $4^{\circ}$; art. 156, $\S 1^{\circ}$; art. 182, $\S 4^{\circ}$, II; art. 195, $\S 9^{\circ}$ (contribuição social devida pelo empregador) - inexiste espaço de liberdade decisória para o Congresso Nacional, em tema de progressividade tributária, instituir alíquotas progressivas em situações não autorizadas pelo texto da Constituição. Inaplicabilidade, aos servidores estatais, da norma inscrita no art. 195, § $9^{\circ}$, da Constituição, introduzida pela EC 20/98. A inovação do quadro normativo resultante da promulgação da EC 20/98 - que introduziu, na Carta Política, a regra consubstanciada no art. 195, $\S 9^{\circ}$ (contribuição patronal)

- parece tornar insuscetível de invocação o precedente firmado na ADI 790/ DF (RTJ 147/921). A TRIBUTAÇÃO CONFISCATÓRIA É VEDADA PELA CONSTITUIÇÃO DA REPÚBLICA. - A jurisprudência do Supremo Tribunal Federal entende cabível, em sede de controle normativo abstrato, a possibilidade de a Corte examinar se determinado tributo ofende, ou não, o princípio constitucional da não-confiscatoriedade, consagrado no art. 150, IV, da Constituição. Precedente: ADI 2.010-MC/DF, Rel. Min. CELSO DE MELLO. - A proibição constitucional do confisco em matéria tributária nada mais representa senão a interdição, pela Carta Política, de qualquer pretensão governamental que possa conduzir, no campo da fiscalidade, à injusta apropriação estatal, no todo ou em parte, do patrimônio ou dos rendimentos dos contribuintes, comprometendo-lhes, pela insuportabilidade da carga tributária, o exercício

\footnotetext{
63 BRASIL. Supremo Tribunal Federal. Pleno, MS n. 16.912.

${ }^{64}$ Cf. TÁCITO, Caio, op. cit., p. 190.

65 "Entendemos, em suma, que a validade da norma de lei, ato emanado do Legislativo, igualmente se vincula à observância da finalidade contida na norma constitucional que fundamenta o poder de legislar o abuso do poder legislativo, quando excepcionalmente caracterizado, pelo exame dos motivos, é vício especial de inconstitucionalidade da lei pelo divórcio entre o endereço real da norma atribuitiva da competência e o uso ilícito que a coloca a serviço de interesse incompatível com a sua legítima destinação". TÁCITO, Caio, op. cit., p. 193. ${ }^{66}$ BRASIL. Supremo Tribunal Federal. Rel. Min. Celso de Mello, ADC 8/DF, Pleno,
} 
do direito a uma existência digna, ou a prática de atividade profissional lícita ou, ainda, a regular satisfação de suas necessidades vitais (educação, saúde e habitação, por exemplo). A identificação do efeito confiscatório deve ser feita em função da totalidade da carga tributária, mediante verificação da capacidade de que dispõe o contribuinte - considerado o montante de sua riqueza (renda e capital) - para suportar e sofrer a incidência de todos os tributos que ele deverá pagar, dentro de determinado período, à mesma pessoa política que os houver instituído (a União Federal, no caso), condicionando-se, ainda, a aferição do grau de insuportabilidade econômico-financeira, à observância, pelo legislador, de padrões de razoabilidade destinados a neutralizar excessos de ordem fiscal eventualmente praticados pelo Poder Público. Resulta configurado o caráter confiscatório de determinado tributo, sempre que o efeito cumulativo - resultante das múltiplas incidências tributárias estabelecidas pela mesma entidade estatal - afetar, substancialmente, de maneira irrazoável, o patrimônio e/ou os rendimentos do contribuinte.

- O Poder Público, especialmente em sede de tributação (as contribuições de seguridade social revestem-se de caráter tributário), não pode agir imoderadamente, pois a atividade estatal acha-se essencialmente condicionada pelo princípio da razoabilidade. A CONTRIBUIÇÃO DE SEGURIDADE SOCIAL POSSUI DESTINAÇÃO CONSTITUCIONAL ESPECÍFICA. - A contribuição de seguridade social não só se qualifica como modalidade autônoma de tributo (RTJ 143/684), como também representa espécie tributária essencialmente vinculada ao financiamento da seguridade social, em função de específica destinação constitucional. A vigência temporária das alíquotas progressivas (art. $2^{\circ}$ da Lei $\mathrm{n}^{\circ}$ 9.783/99), além de não implicar concessão adicional de outras vantagens, benefícios ou serviços - rompendo, em conseqüência, a necessária vinculação causal que deve existir entre contribuições e benefícios (RTJ 147/921) — constitui expressiva evidência de que se buscou, unicamente, com a arrecadação desse plus, o aumento da receita da União, em ordem a viabilizar o pagamento de encargos (despesas de pessoal) cuja satisfação deve resultar, ordinariamente, da arrecadação de impostos. Precedente: ADI 2.010-MC/DF, Rel. Min. CELSO DE MELLO.

O poder de tributar, necessariamente, deverá guardar estrito respeito às normas Constitucionais. ${ }^{67}$

Nesse sentido foram construídas as Súmulas de nos 70 e 323 do STF, litteris:

Súmula 70/STF - É inadmissível a interdição de estabelecimento como meio coercitivo para a cobrança de tributo.

Súmula 323/STF - É inadmissível a apreensão de mercadorias como meio coercitivo para pagamento de tributos.

Os tributos, nas suas diversas espécies, compõem o Sistema Constitucional tributário, que a Constituição estabelece nos seus arts. 145 a 
162. Sua definição vem albergada no art. $3^{\circ}$ do CTN, definição que se resume, em termos jurídicos, em uma obrigação que a lei impõe às pessoas de pagar, em dinheiro, certa importância ao Estado. Assim, o exercício arbitrário e excessivo do legislador tem gerado repúdio por parte de inúmeros julgadores do Colendo STF.

Exemplo claro do afirmado, além dos que foram citados anteriormente, consiste na impossibilidade de fixação de alíquotas progressivas do IPTU:

IPTU - Progressividade - No sistema tributário nacional é o IPTU inequivocamente um imposto real — Sob o império da atual Constituição, não é admitida a progressividade fiscal do IPTU, quer como base exclusivamente no seu art. 145 , parágrafo $1^{\circ}$, porque esse imposto tem caráter real que é incompatível com a progressividade decorrente da capacidade econômica do contribuinte, quer com arrimo na conjugação desse dispositivo Constitucional (genérico) com o artigo 156, parágrafo $1^{\circ}$ (específico). A interpretação sistemática da Constituição conduz inequivocamente a conclusão de que o IPTU com finalidade extrafiscal a que alude o inciso II do artigo 182 é a explicação especificada, inclusive com a limitação temporal do IPTU com a finalidade extrafiscal aludida no art. 156, I, parágrafo $1^{\circ}$. Portanto, é inconstitucional qualquer progressividade, em se tratando do IPTU, que não atenda exclusivamente ao disposto no artigo 156 , parágrafo $1^{\circ}$, aplicando com as limitações expressamente constantes dos parágrafos $2^{\circ} \mathrm{e} 4^{\circ}$ do artigo 182, ambos da Constituição Federal Recurso extraordinário conhecido e provido, declarando-se inconstitucional o subitem 2.2.3 do setor II da tabela III da Lei no 5.641, de 22/12/1989, no Município de Belo Horizonte. ${ }^{68}$

O abuso do poder do órgão legislativo também se configura pela omissão, como observado pelo nosso ilustre Min. Aldir Passarinho: ${ }^{69}$

A Ação Direta de Inconstitucionalidade por omissão, de que trata o $§ 2^{\circ}$ do art. 103 da nova CF, não é de ser proposta par que seja praticado determinado ato administrativo em caso concreto, mas visa a que seja expedido o ato normativo que se torne necessário para o cumprimento de preceito constitucional que, sem ele, não poderia ser aplicado.

Inúmeros são os desmandos que o STF vem combatendo, fiel ao seu sagrado mandamento de fiscalizar os Poderes Executivo e Legislativo, confrontando seus atos com o que vem estabelecido na Constituição Federal, quando, no exercício de suas prerrogativas, os referidos poderes rompem a legalidade ou outros princípios da Carta Política.

\footnotetext{
67 "O fundamento do poder de tributar, por isso mesmo, reside no dever jurídico de essencial e estrita fidelidade dos entes tributantes ao que imperativamente dispõe a Constituição da República. (Despacho do Minstro-Presidente Celso de Mello, Informativo STF, n. 125).
} 


\section{Conclusão}

Após todo o exposto, se conclui, com toda convicção, que o STF, como responsável maior do Judiciário, não tem decepcionado os jurisdicionados, quando demonstrado excesso ou abuso de poder por parte de autoridade ou de determinado Órgão Público.

Possui o direito vários mecanismos para garantir o plasmado que norteia o nosso Estado Democrático de Direito, que é o respeito às garantias contidas na Carta Magna, destinando-se, dentre outros valores, assegurar a liberdade e a segurança jurídica.

Ninguém - aí incluam-se os Poderes legalmente constituídos possui a faculdade de rasgar a Constituição, para instituir uma sociedade onde os excessos ou abusos seriam uma constante. O princípio é o de que todos, em especial o Estado, devem comungar da hóstia constitucional, pautando seus atos dentro do encarte legal, sem sentimentos ou posicionamentos ilegais.

Portanto é que se clama sempre por um Judiciário independente, onde o Magistrado somente se curva à sua própria consciência jurídica e moral.

Muitas são as tentativas de inibição do magistrado, que possui o sério fardo de resgatar a dignidade de quem sofre abusos ou injustiças.

O grande alento que se possui é que, mesmo carente de estrutura, a máquina do Judiciário tem funcionado com louvor, graças à determinação destes grandes magistrados, que contra tudo e contra todos, vêm impondo a justiça em nosso país.

\footnotetext{
68 BRASIL. Supremo Tribunal Federal. Rel. Min. Moreira Alves, RE nº 153.771-0/MG, Decisão de 20/11/96. ${ }^{69}$ BRASIL. Supremo Tribunal Federal. Rel. Min. Aldir Passarinho, ADIN n 10-5/AL, Pleno, julgado em 14/4/1989.
}

A \& C R. de Dir. Administrativo e Constitucional, Belo Horizonte, ano 4, n. 16, p. 77-106, abr./jun. 2004 
A \& C R. de Dir. Administrativo e Constitucional, Belo Horizonte, ano 4, n. 16, p. 77-106, abr.jun. 2004 